\title{
Search for Harmony in the Works of Multimedia Artist Mariia Kulykivska and Photographer Mark Neville
}

\author{
Kramarenko Yaroslava Ihorivna \\ Postgraduate; \\ T.H. Shevchenko National University "Chernihiv Collegium”; \\ O.M. Lazarevsky Educational and Scientific Institute of History and Socio- \\ Humanitarian Disciplines; \\ sub-faculty of Law, Philosophy and Political Science; \\ Myru Avenue, 13, 14000, the City of Chernihiv, Ukraine
}

\begin{abstract}
The article examines the concept of "harmony" as a state of contradictions and its role in modern art, particularly, in actionism, as well as the theories of the inner "man" and "self". The works of artists Mariia Kulykivska and Mark Neville, who form a creative format of modern Ukraine, are studied. It is analyzed how "the art of action", despite its somewhat revolutionary and pretentious nature, can embody the unity of opposites. It is argued the phenomenon of modern art is precisely in harmony that creates "higher" values and generates a positive assessment of reality, suppressing its flaws and problems. The author concludes actionism has completely integrated with its multifaceted form into Ukrainian sociocultural space, and therefore it gradually frees itself from outdated stereotypes and formalized approaches, adapting to the best examples of world artistic experience.

Key words: harmony, actionism, art photography, performance, School of Political Performance, sculptural clones, culture, modern art, "self", "pearl theory".
\end{abstract}

The problem definition. In recent years, a large number of creative groups and individual artists have appeared in Ukraine, realizing various actions, platforms, installations, exhibitions etc. Some of them are eccentric, others are scandalous, and there are those imbuing with extraordinary sensuality, forcing to embrace their idea and think about own life harmony.

The most interesting in actionism, particularly, in performance, is the ability to create synergy: combine completely different types of art, ideas, materials, forms that do not seek for primacy, but on the contrary complement each other. Photographers, singers, architects, poets - this is an incomplete list of artists developing a creative format of modern Ukraine, and their works are worth publicity and careful study. Nobody remains indifferent to performances that carry not only regulated time allotted to pay attention to a particular social issue, but also informational, educational or even esthetic and pedagogical missions. A special atmosphere, "aura", warm-heartedness are always felt in such works. 
We all try to find the essence of our "man", inner balance, creating appropriate conditions for this. At the same time, we strive for harmony with a controversial social order and nature that is constantly negatively affected by a human, as well as with the world in general. However, how about "art of action"? Is it possible to "design" harmony using its forms and somewhat revolutionary, pretentious character? After all, this movement merged with reality long ago and this suggests considering it a fully integrated, multifaceted form of Ukrainian sociocultural space. It gradually frees itself from outdated stereotypes and formalized approaches, adapting to the best examples of world artistic experience.

The phenomenon of modern art is in harmony that creates "higher" values, generates a positive assessment of reality, suppressing its flaws and problems. This is how being is perceived by an individual: a stable, living system bearing coherence and interconnectivity of harmony in its core. If this statement seems strange, one should mention philosopher St. Augustine's words: “A miracle does not contradict the law of nature. It only contradicts our understanding of nature" [6, p. 7].

Researches and publications analysis. The culture of harmony, as well as various forms of actionism, are currently experiencing rise in their development process, because a human of modern post-industrial society tends to admire self-knowledge and position oneself, especially through art perceived differently by its creators and viewers. Yet the individuality of harmony remains phenomenal for each of us.

Modern scientists and philosophers interpret this concept differently. The ideas of Confucius and his school, neo-Confucianism, Heraclitus, Pythagoras, Plato and Aristotle had a significant impact on them. It were historical figures of ancient China and Greece who initiated separate directions in harmony understanding and perception. Those of European and American thinkers who seized that matter were G.W. Leibniz, Ch. Fourier, J. Goethe, I. Kant, G. Hegel, A.N. Whitehead, J. Maritain, J. Dewey, A. Lamouche, Ch. Lalo, E. Cassirer, F.A. Lange and D. Parker. The issue about a personality's harmonious development was studied by A.F. Polis and A.A. Milts.

Setting out the article objectives. The author substantiates how exactly internal process of harmonization influences Mariia Kulykivska and Mark Neville's artistic and esthetic activity; characterizes a harmonious specificity of performance as an art form of actionism; determines basic principles to achieve harmony through the inner "man" in art projects. 
Presenting main material. Harmony (gr. harmonia - connection, orderliness) - is the idea of integrity and perfection of an esthetic object's organization that arises from qualitative and quantitative differences and even struggle of its elements. Quite often harmony is considered basic or imperative for beauty. This is a complex esthetic category with a wide meaning. One may refer to a harmonious structure of the universe, nature or its individual elements, a human body, art works as well as a personality's balanced development. Harmony is closely related to a number of esthetic concepts, such as symmetry, rhythm, proportion and ideal that are its elements [1, p. 215].

This article author began researching the harmony concept with Mariia Kulykivska's works created in "Isolation" - a small art studio in Donetsk [5]. When studying her activity in detail, special attention was paid to the School of Political Performance: "It was registered as a public non-profit organization since May 2017. I believe its very first project was my unauthorized performance during "Manifesta' 10" opening on July 1, 2014, where I was lying on Hermitage steps, covered with the Ukrainian flag. It was called " 254 " like my number of a migrant from Crimea. At that time, I did not yet think about the school. It simply did not exist, but it was the beginning [9].

After that, in 2016 there were actions on mined Mariupol beach and "Crimea Raft" performance that became the culmination of shaping the school concept. According to the artist herself, "Many of our troubles are because we have almost absent humanitarian education. There is no serious school teaching the society to think conceptually and critically, as well as artists and cultural workers to go beyond traditional mediums of art" [9].

Mariia constantly turns to sculpture in her creative practice. She designs the series of own busts not only to trace transformation of the materials used, but also to define the idea of a human body harmonious existence in a public space. While experimenting, the artist returns to the "vanitas" tradition, when a person appears "a soap bubble" and one's fragile life is emphasized. Mariia creates sculptural clones from different materials (wax, soap, epoxy resin) and fills the middle with flowers, chains, feathers, shells and even bullets: "I consider human skin as a kind of a membrane carrying very many hidden subtexts" [7]. While being interviewed by "Public Television", she described moral and physical feelings after learnt about a kind of "performance" by pro-Russian militants who had shot her sculptures and about "Isolation" studio they had turned into a prison. The artist felt a complete esthetic imbalance because of 
that, since beauty, uniqueness and essence of her works had turned into crippled and wounded targets.

The Chinese philosopher and culturologist Gordon Wang wrote in his book "On the Culture of Harmony: Where Are Human Beings Headed?” that “...human bodies are a small universe and harmony is a main guarantee of its infinite prosperity" [6, p. 12]. This quote's essence is reflected in Mariia Kulykivska's works: "I first made soap sculptures in 2012. I was interested in studying their transformations until 2014 when they were shot. I create "bodies" and give them to the world. And then they live, something happens to them, it is their own story. At the same time, it allows to look into future: I do not really know how I will grow old, how I will die, how my body will decompose. It may sound scary, but there is a certain beauty in it - more beauty than perfection" [7].

Organizing her sensual performances, the artist thus analyses and confirms the inner "man" existence via memories, holistic perception of time, space and other people; hence the feeling of "self". Modern philosopher Julian Baggini explained in his "pearl theory" that “...body and brain provide us with a strong and continuous sense of "self" that gives us freedom to create ourselves. No matter how much we change over time, there is some inner being that remains inalterable" [3, p. 50-51].

The Scottish philosopher and publicist David Hume suggested a human has neither a single centre nor a holistic "man" or soul. Instead, we are a chaotic set of feelings that are constantly changing, and the way to perceive things and events becomes gradually fixed by this provision [3, p. 191].

The two positions above assist in studying harmony essence and significance in performance art. After all, its basics are laid in feelings, thoughts, actions that seem unclear, sometimes unacceptable, are criticised or conversely exalted to the beautiful. We may not be who we were five or ten years ago, but we remain individuals all our life. A constant search for comfort and "place of power" encourages addressing art works and analysing them, therefore we have modifications indicating our natural desire for "inner balance". As for performance, it does not have a specific esthetic direction, and this causes ambiguity in perception of what was seen. A performer is one who approves its content: socio-political aspect, time, provocation. Under such conditions, it is impossible to play performance on the script. An artist lives a whole process in moment and involves viewers, surprising them with a harmonious reciprocity 
between daily and artistic life. In summary, the question arises: so where is harmony of performance art manifested? It is in a series of personal feelings and opportunity to address a wide audience, demonstrating own struggle, traumatic experience, disagreement, protest, and above all, to be heard. Every author forms own "harmonious" view by a unique performance manner.

Another subject philosophers are still desperately discussing is the unity of soul and body. There is a well-known theory of dualism introduced at different times by Plato and Descartes, where soul is consciousness and body is a physical matter, i.e. reality. Two other theories worth noting are idealism and materialism. If the first does not imagine existence of reality outside consciousness, the second, in contrast, criticizes dualists and idealists.

In the case of Maria Kulikovska, we may objectively assume that her sculptures' "corporeality" is really endowed with a "soul"; however, it exists independently, outside an object. It is not easy for the artist to perform another series of casts of her likeness, and she periodically suffers from panic attacks when a hardening texture is laid on her. We consider harmony is manifested exactly in this process. Such is Maria's method to explore a human body and its external changes through her works. She exposes herself to certain phobias and inconveniences, but consequently creates a symmetrically proportional body of a woman who is the idea of a harmonious existence.

Incredibly insightful exhibition "Flowers" is a fruitful union of Swedish artist Alexandra Larsson-Jacobson and Mrs. Kulikovska, who created works with her husband architect Uleg Vynnychenko and a director Alina Gontar. This dialogue between the two artists turns into a polylogue with society and learning a human "shell" in socio-political relations context.

Multicoloured busts symbolize people born in postcolonial or colonial conditions as the author herself: "I am Ukrainian, but my first language is Russian. Greetings from a postcolonial childhood! And the word "flowers" in it is also associated with "colour" and its shades, not just a flower. This wordplay is a very important aspect of the whole exhibition idea where I talk about different physical and metaphorical shades of skin, a human shell” [9].

Each of us has his own pain, tragedies or memories about government oppression or its agencies bureaucracy. However, there is something that changes our priorities and creates a certain emotional space. This "something" is colours in "Flowers" project, and in life it is our values and relationships. 
The art world is so diverse that it surprises us with unusual forms, sounds, colours, light and so on. It would seem to be chaotic, but there is a balance here. Artists are not the only ones who try to emphasize and achieve composition harmony as their most cherished goal.

The British photographer and sculptor Mark Neville claims to work at the intersection of art photography and documentary. Once being interviewed, he spoke about the events struck him in Afghanistan, working with "New York Times" and photographing in Ukraine [10]. We got interested in the subject of his works on the war in Donbass: they show soldiers on the front line and ordinary people depicted in real living conditions and circumstances. They were "alive", in camouflage, amidst poverty and dugouts, shattered homes. The photos sometimes show children with teary eyes and pets sitting on their dirty hands. However, even in broken foundations or off-road that are isolated and deprived of feelings of security and peace, one can feel harmony.

In 2017 Mark Neville participated in Berlin Centre for Eastern European and International Studies (ZOiS) project "The Displaced Ukrainians. Who are They and What do They Think?" The author notes the best 50 photos were selected from several thousand: "I am really very proud of these works. I think these are very keen images. It took much effort to achieve this. The project also includes a one-and-a-half-hour video about migrants from Donbass and Crimea" [10].

For Mark it was a mutually beneficial collaboration, a combination of art and research. Sometimes artists, gathering facts and figures, lose the "human factor", turning the material into dry statistics of heartlessness. However, Mr. Neville managed to recreate life stories in live photo reports, and their harmonious atmosphere remained genuine.

"We want to make a kind of" interweaving "of traditional folk songs with social research. The result should be a slide show: my photos and live vocals. By 2020, we plan to prepare this live performance. It will be presented in Berlin at the end of next year. We also hope for a tour of Ukraine with this show and performance in London," Mark Neville said in an interview for "Ukrinform" [10].

The photographer shoots only on film, believing that this is how he will fully convey emotions and depth of colour. It depicts inconspicuous objects, brave, destitute, frightened adults and children in bombed-out houses, and just those who resigned themselves to the events, got used to the shots, but did not stop believing in Ukraine's victory in the war in Donbass. Most 
smile, sometimes even with their eyes, and sometimes through tears. For them, harmony is not in high matters, not in complex terms, and even more so not in philosophical categories. For them, it is a peaceful life in their homeland.

"Until I went to Ukraine, I had never met such proud, stable, generous people. No one has ever said, "Can you help? Give me something. "After all, it is natural in such circumstances to ask for it. They immediately understood that I was doing an important thing - I could tell with my work about what was happening. They were very generous and ready to show and explain everything. I have never felt this way before. It impressed me," - Mark shared his impressions [10].

Conclusions. Performance has changed dramatically, ceased to be a familiar version of himself and crossed the line of classical interpretation. Maria Kulikovska and Mark Neville have created works that are completely distant from each other, in which different emotions, ideas and goals are experienced. The only thing that unites them is harmony. It is present in the use of materials, techniques, presentation, involvement of other arts. The authors allowed us to move away from the traditional perception of what we saw. Such performances arouse the desire to study actionism in more detail, to explore the processes of creating incredible projects in which the principle of harmony prevails over the monotony of human needs. From this point on, you begin to appreciate content and rethink things that seemed unnecessary or indifferent. Harmony cannot be explained in one word. This is such a feature, sometimes even a state, it can be felt, expressed, shared.

Culturology and philosophy define at least three main types of ideas about harmony: artistic, mathematical, aesthetic. But very seldom did they meet in a "pure" form, alone, because they were strongly intertwined with each other and created a certain unity. But in each historical epoch one of the types of the concept of harmony manifested itself in the role of the main, dominant.

Modern aesthetic science freely uses the philosophical category of "harmony". One of its primary problems is the question of balance in nature and even more so in the universe. Is there a correspondence between the dimensions of man and nature? Aesthetics seeks answers to these questions in the large-scale context of philosophical knowledge. And an extremely important direction in the study of harmony is the solution of current problems in ecology, the coexistence 
of man and nature, the reproduction and preservation of the latter, as well as the individual as an artist. The need to educate a person who has the concept of harmony remains quite relevant.

Helena Bonham Carter - the British actress of theatre, film and television - said wonderful words describing the philosophy of harmony in our lives: "I think everything in life is art. What you do, how you dress. How do you love someone and how do you say. Your smile and your personality. And all your dreams. How do you drink tea, how to decorate your home or how to have fun. Your shopping list. The food you cook. What your handwriting looks like. How you feel. Life is an art".

\section{References}

1. Adorno T. Teoriia estetyky. Kyiv : Osnovy, 2002. $518 \mathrm{~s}$.

2. Baggini J. The Ego Trick: What Does It Mean to Be You?. London : Granta Books, 2012. $304 \mathrm{p}$.

3. Batler-Boudon T. 50 velikikh knig po filosofii. Kiev : Fors, 2019. $432 \mathrm{~s}$.

4. Dobronosova Yu. D. Harmoniia (v estetytsi). Velyka ukrainska entsyklopediia. URL: https://vue.gov.ua/Гармонія_(в_естетиці) (data zvernennia: 15.10.2021).

5. Humeniuk N. "Nepryiemno, koly hovoriat: u vas krymska reiestratsiia, tomu vy ne rezydentka Ukrainy", - khudozhnytsia Mariia Kulikovska. Hromadske.ua. URL: https://hromadske.ua/posts/nepriyemno-koli-govoryat-u-vas-krimska-reyestraciyatomu-vi-ne-rezidentka-ukrayini-hudozhnicya-mariya-kulikovska (data zvernennia: 19.12.2019).

6. Khe Fen. Kultura harmonii. Kyiv : ArtHuss, 2019. $208 \mathrm{s.}$

7. Khomchenko M. Mariia Kulikovskaia: "Ia rassmatrivayu kozhu cheloveka kak nekuyu obolochku, membranu, kotoraia nosit v sebe ochen mnogo skrytykh podtekstov. Your Art. URL: https://supportyourart.com/conversations/kulikovska/ (data zvernennia: 3.02.2020).

8. Papash O. Khudozhnitsa Mariia Kulikovskaia: My vse, vsia Ukraina - pereselentsy. Ukrainska pravda. URL: https://life.pravda.com.ua/culture/2016/08/12/216512/ (data zvernennia: 12.08.2016).

9. Seleznova Ye. Hovoryt khudozhnytsia: Mariia Kulikovska, "Moia shkira - moia sprava". Prostir. URL: https://www.prostranstvo.media/uk/govoryt-hudozhnyczya-mariyakulikovska-moya-shkira-moya-sprava-ru/

10. Tanasiichuk O. Mark Nevill, brytanskyi fotohraf. Do Ukrainy ya nide ne zustrichav takykh hordykh i vidkrytykh liudei. Ukrinform. URL: https://www.ukrinform.ua/rubricworld/2364409-mark-nevill-britanskij-fotograf.html (data zvernennia: 17.12.2017). 